\title{
Pemanfaatan Limbah Feses Sapi sebagai Pembuatan Pakan Pelet terhadap Pertambahan Berat Badan Ikan Lele Dumbo
}

\author{
(Utilization of Cattle Feces as Materials for Pellet Feed \\ to the Weight Gain of Catfish) \\ Zulhelmi ${ }^{1}$, Cut Aida Fitri ${ }^{1}$ M. Aman Yaman ${ }^{1}$ \\ ${ }^{1}$ Program Studi Peternakan, Fakultas Pertanian, Universitas Syiah Kuala
}

\begin{abstract}
Abstrak. Penelitian ini bertujuan untuk memanfaatkan limbah asal feses sapi sebagai bahan pembuatan pakan pelet guna memacu pertumbuhan ikan Lele Dumbo. Penelitian ini dilakukan di Station Riset II (dua) Ie Suum, UPT. University Farm, Aceh Besar, tanggal 22 Mei-14 Agustus 2016. Rancangan penelitian yang digunakan adalah Rancangan Acak Lengkap (RAL) terdiri dari 4 perlakuan dan 4 ulangan. Setiap ulangan merupakan unit percobaan, masing-masing terdiri dari 50 ekor ikan Lele Dumbo. Perlakuan menggunakan pakan komersil ikan 781 Hiprovite yang disubtitusikan dengan pakan pelet organik. Parameter yang diamati adalah berat badan, pertambahan berat badan, konsumsi pakan, konversi pakan, efisiensi pakan, kelangsungan hidup, dan kualitas air ( $\mathrm{pH}$, suhu, kelembaban, cahaya). Hasil penelitian menunjukkan perlakuan pakan limbah asal feses sapi berpengaruh sangat nyata $(\mathrm{P}<0.01)$, terhadap berat badan, pertambahan berat badan, dan konsumsi ransum ikan Lele Dumbo, namun tidak berpengaruh nyata $(\mathrm{P}>0,05)$ terhadap konversi dan efisiensi pakan. Dari hasil penelitian ini dapat disimpulkan bahwa pakan pelet organik asal feses sapi dapat memacu pertumbuhan ikan Lele Dumbo.
\end{abstract}

Kata kunci : feses sapi, probiotik, ikan lele, berat badan.

\begin{abstract}
The aim of present study was to utilizase cattle feces as materials for making organic pellet feed to improve the growth of catfish. The study was conducted in Station Research II (two) Ie Seum Unit, University Farm, Aceh Besar, May 22-August 14, 2016. The study was designed into completely randomized design (CRD) consisting of 4 treatments and 4 replications. Each relication was an experimental unit consisting of 50 catfishes. The treatment was substition of commercial feed fish (781 Hiprovite) with organic pellet feed with the level of 0, 10, 20, and $30 \%$, respectively. Parameters measured were body weight, feed intake, feed conversion, feed efficiency, livebility, and water quality $(\mathrm{pH}$, temperature, moisture, light). The results of study showed that administration of organic pellet feed affected highly significant $(\mathrm{P}<0.01)$ on body weight, body weight gain and feed intake of catfish. However, there were no significant effect $(\mathrm{P}>0.05)$ on feed conversion and feed efficiency. It was concluded that the organic pellet feed composed mainly from cattle feces could improve the growth of catfish.
\end{abstract}

Keywords: feces, probiotics, catfish, body weight.

\section{PENDAHULUAN}

Limbah peternakan yang dihasilkan dari budidaya peternakan dapat diperbaharui dan dimanfaatkan untuk berbagai produk, terutama limbah padat dan cair. Limbah ternak sangat kaya akan nutrisi (zat makanan) seperti protein, lemak, bahan ekstrak tanpa nitrogen, vitamin, mineral, mikroba atau biota. Limbah ternak berpotensi sebagai bahan makanan ternak, pupuk organik, energi untuk media tumbuh dengan berbagai tujuan, saat ini limbah ternak juga dapat dijadikan 
sebagai bahan alternatif penyusun pakan ikan. Budidaya perikanan untuk pakan ikan masih tergantung pada pakan pabrikan atau yang sering disebut pelet yang harganya mahal. Hal ini disebabkan oleh tingginya biaya produksi pelet ikan terutama pengadaan bahan baku. Jika bahan baku pembuatan pakan ikan dapat disubstitusi dengan bahan yang tersedia didaerah sekitar seperti limbah ternak, sehingga harga pengadaan bahan baku pakan bagi kelangsungan usaha budidaya ikan dapat ditekan sehingga keuntungan yang diperoleh lebih besar. Bahan baku pakan yang utama adalah komponen protein yang diperoleh dari sumber hewani ataupun nabati.

Berdasarkan hasil pengamatan dalam prapenelitian, feses sapi yang ditambah bungkil kedelai dan dedak halus dapat dimanfaatkan sebagai pakan alternatif untuk ikan Lele Dumbo dengan biaya pakan menjadi lebih murah. Pemanfaatan feses sapi sebagai pakan ikan juga dapat menjaga kelestarian lingkungan dan mencegah polusi serta mampu memacu produksi ikan Lele Dumbo.

Agar pakan non-komersil mampu dimanfaatkan oleh ikan untuk pertumbuhan dalam pemanfaatan feses perlu ditambahkan probiotik. Diharapkan probiotik akan mampu membantu kecernaan pakan sehingga pertumbuhan ikan akan lebih cepat. Namun demikian penelitian terkait dengan hal tersebut masih sangat kurang, untuk memperkuat dan memperoleh data yang akurat perlu dilakukan penelitian agar mengetahui manfaat dari limbah ternak sapi sebagai bahan pakan ikan Lele Dumbo.

\section{Tempat dan Waktu}

\section{METODE PENELITIAN}

Penelitian ini dilakukan di Station Riset II (dua) Ie Seum UPT. University Farm, Universitas Syiah Kuala, Aceh Besar. Penelitian berlangsung selama 90 hari, mulai tanggal 22 Mei sampai 14 Agustus 2016.

\section{Materi Penelitian}

Penelitian dilaksanakan dengan membuat pakan pelet organik berbahan limbah feses sapi, bungkil kedelai, dedak halus dan probiotik. Untuk menguji pakan buatan tersebut langsung diaplikasikan pada ikan Lele Dumbo sebanyak 800 ekor dengan berat rata-rata 1,55 gram/ekor dan panjang $10-11 \mathrm{~cm}$ yang dipesan melalui Poultry Shop.

\section{Pelaksanaan Penelitian}

a. Tahap persiapan : menyiapkan pakan dan kolam terpal terlebih dahulu, dilanjutkan dengan proses perendaman kolam untuk menghilangkan bau terpal.

b. Tahap Pemeliharaan: ikan dengan ukuran 1,55 gram/ekor ditebar ke dalam kolam penelitian dengan kepadatan 50 ekor/keramba. Ikan diadaptasikan terlebih dahulu dengan pakan uji sampai kenyang pada pagi, siang dan sore hari.

c. Tahap Pengambilan Data: data yang diukur dari awal hingga akhir penelitian adalah berat badan akhir, pertambahan berat badan, konsumsi 
pakan, efisiensi pakan, konversi pakan, kelangsungan hidup dan derajat keasaman $(\mathrm{pH})$.

\section{Parameter Penelitian}

Parameter yang akan diamati didalam penelitian adalah performan ikan Lele selama pemeliharaan 90 hari, yang meliputi:

a. Berat badan, diperoleh dengan cara menimbang ikan, dan dinyatakan dalam satuan gram/ekor.

b. Pertambahan Berat Badan (PBB), diperoleh dengan cara mengurangi bobot badan minggu bersangkutan dengan minggu sebelumnya, dan dinyatakan dalam satuan gram/ekor/minggu.

c. Konsumsi pakan, diperoleh dengan cara mengurangi banyaknya pakan yang diberikan dengan pakan sisa, dan dinyatakan dalam satuan gram/ekor.

d. Efisiensipakan, diperoleh dengan cara membagi pertambahan berat badan dengan konsumsi pakan.

e. Konversi pakan atau FCR (Feed Convertion Ratio) diperoleh dengan cara membagi konsumsi pakan dengan pertambahan berat badan, dan dinyatakan dalam satuan gram pertambahan berat badan/gram konsumsi pakan.

f. Mortalitas, diperoleh dengan cara membagi banyaknya ikan Lele yang mati dengan banyaknya ikan Lele yang dipelihara dikali seratus persen, dan dinyatakan dalam satuan $\%$.

\section{Analisis Statistik}

Data aspek produksi yang diperoleh dianalisis dengan Analysis of Variance (ANOVA). Jika dari analisis tersebut didapatkan hasil yang berbeda nyata, maka dilanjutkan dengan uji Duncan (Steel dan Torrie, 1993).

\section{HASIL DAN PEMBAHASAN}

\section{Berat Badan}

Berdasarkan pengamatan penelitian dengan pemberian pakan limbah feses sapi dan probiotik selama penelitian, pada level $90 \%$ pakan komersil dan $10 \%$ pemberian pakan pelet organik menunjukkan nilai pertumbuhan berat badan sebesar 142,75 (gram/ekor), hal tersebut dikarenakan kandungan nutrisi pada pakan perlakuan masih dalam kisaran zat gizi yang dibutuhkan oleh ikan Lele Dumbo untuk laju pertumbuhan yaitu protein kasar 31,80\%, lemak kasar 5,82\% dan serat kasar 4,95\%. Pakan pelet organik mempunyai kandungan protein, serat kasar, dan lemak yang akan dicerna untuk pertumbuhan ikan. Subandiyono (2009), menyatakan protein, serat kasar, dan lemak dapat dicerna dan dimetabolisme oleh tubuh ikan lalu diubah menjadi energi yang dimanfaatkan untuk pertumbuhan. Madinawati et al. (2011), menyatakan bahwa pertumbuhan berat badan terjadi karena adanya kelebihan energi yang berasal dari pakan.

Pakan pelet organik mempunyai kandungan protein, serat kasar, dan lemak yang akan dicerna untuk pertumbuhan ikan. Subandiyono (2009), menyatakan protein, serat kasar, dan lemak dapat dicerna dan dimetabolisme oleh tubuh ikan lalu diubah menjadi energi yang dimanfaatkan untuk pertumbuhan. Madinawati et 
al. (2011), menyatakan bahwa pertumbuhan berat badan terjadi karena adanya kelebihan energi yang berasal dari pakan.

Menurut Pramono (2007), kandungan nutrisi dan tingkat kecernaan di dalam pakan merupakan faktor pembatas dalam suatu model pertumbuhan, protein merupakan komponen utama dalam pembentukan jaringan dan organ-organ tubuh. Akan tetapi kebutuhan protein pada ikan bervariasi dari jenis ikan, meskipun demikian protein merupakan unsur kunci utama kebutuhan ikan untuk pertumbuhan, dari kandungan nutrisi pakan tiap perlakuan berbeda, semakin tinggi persentase pakan pelet organik menunjukkan semakin tinggi pula serat kasar dan semakin rendah kandungan protein kasar. Rataan berat badan ikan Lele Dumbo setiap perlakuan selama 12 minggu (gram/ekor) disajikan pada Gambar 1.

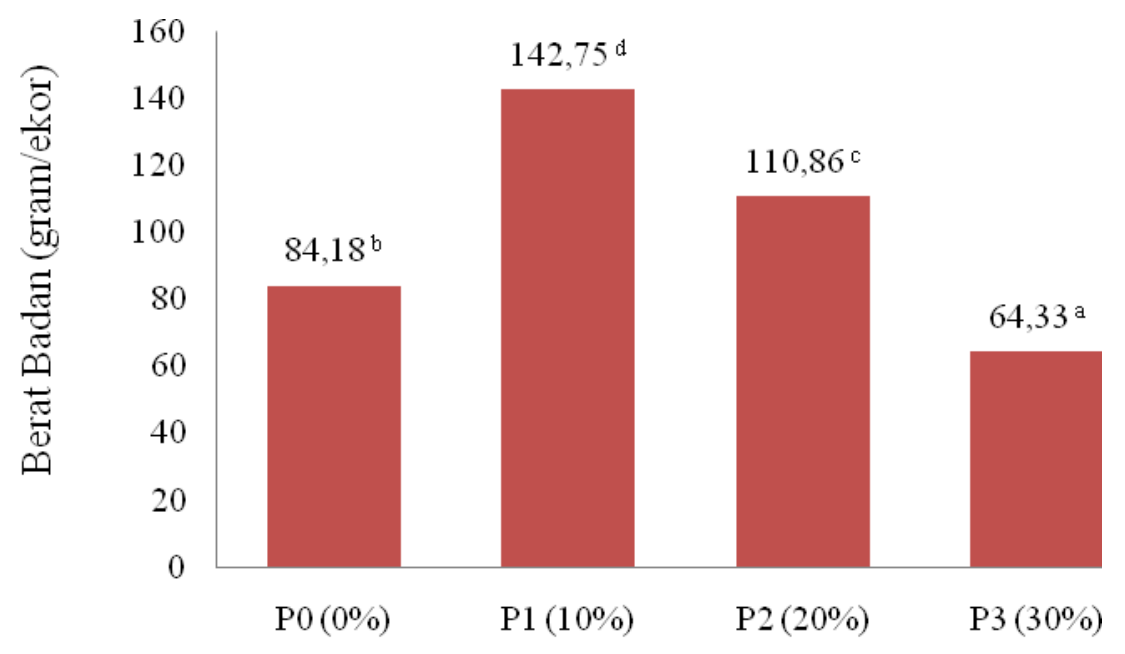

Persentase penambahan pelet organik

a, b, c, d = Huruf (Superscript) y ang berbeda ny ata

Gambar 1. Rataan berat badan ikan Lele Dumbo

Setiap perlakuan selama 12 minggu (gram/ekor)

\section{Pertambahan Berat Badan}

Berdasarkan hasil penelitian pertambahan berat badan disetiap perlakuan berbeda nyata antar perlakuan, pada level pemberian pakan komersil $90 \%+10 \%$ pakan pelet organik $\left(\mathrm{P}_{1}\right)$ mencapai rataan kenaikan tertinggi $70,83 \%$, pada perlakuan pemberian pada level pakan komersil $80 \%+20 \%$ pakan pelet organik $\left(\mathrm{P}_{2}\right)$ mencapai rataan kenaikan 32,29\%, sedangkan pemberian pada level pakan komersil $70 \%+30 \%$ pakan pelet organik $\left(\mathrm{P}_{3}\right)$ mengalami rataan penurunan 24,02\%. Rataan pertambahan berat badan ikan Lele Dumbo setiap perlakuan selama 12 minggu (gram/ekor) disajikan pada Gambar 2. 


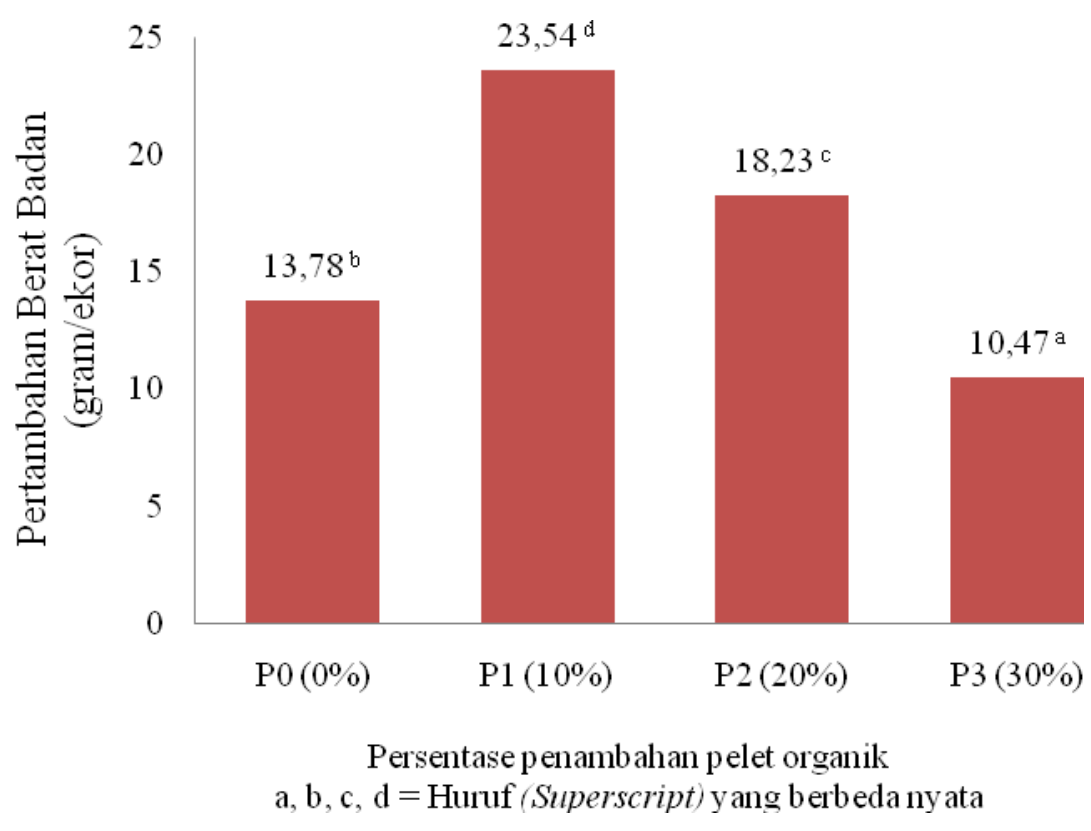

Gambar 2. Rataan pertambahan berat badan ikan Lele Dumbo Setiap perlakuan selama 12 minggu (gram/ekor)

Nilai laju pertambahan berat badan menunjukkan hasil berbanding lurus dengan pertumbuhan berat badan, adanya pertambahan berat badan disebabkan konsumsi pakan ikut bertambah, selain adanya peranan probiotik pada pakan uji, bakteri yang terdapat dalam probiotikdapat meningkatkan kecernaan pakan dan dapat membantu proses penyerapan makanan, sehingga pakan yang dikonsumsi lebih efisien sehingga dapat meningkatkan pertambahan berat badan ikan Lele Dumbo. Probiotik Raja Lele mempunyai kandungan Lactobcillus, Acetobacter, dan Yeast yang dapat membantu pertumbuhan ikan Lele Dumbo. Menurut Wulandari (2008), Yeast di dalam probiotik tersebut berfungsi untuk mengendalikan dan membunuh Mikroflora yang terdapat dalam saluran pencernaan, yang dapat mengganggu proses pencernaan dan penyerapan nutrisi pakan. Sehingga pakan yang diberikan dapat dikonsumsi dengan baik dan diserap oleh tubuh ikan.

Berdasarkan penelitian sebelumnya Arief et al. (2008), bahwa dengan penambahan probiotik berpengaruh terhadap pertumbuhan ikan. Pakan merupakan faktor eksternal yang mendukung pertumbuhan ikan. Ikan Lele Dumbo tumbuh maksimal pada pemberian pakan dengan kadar protein lebih dari 30\%, jika pemberian pakan lebih sedikit, maka diperlukan pakan dengan kadar protein yang lebih tinggi (Halver dan Hardy, 2002). Protein di dalam pakan adalah hal yang sangat penting diperhatikan untuk pertumbuhan ikan, karena protein di dalam pakan ikan berfungsi sebagai komponen penyusun enzim dan hormon yang mengatur proses metabolisme dalam tubuh ikan dan juga bisa memperbaiki jaringan yang rusak serta membentuk jaringan yang baru untuk pertumbuhan ikan Lele Dumbo (Soedarno dan Sedioetama, 1974).

Menurut Parakkasi (1999), protein yang mencukupi dalam pakan dapat meningkatkan pertambahan berat badan. Pakan yang mengandung protein yang rendah akan mempengaruhi atau mengurangi laju pertumbuhan, kekurangan 
protein di dalam pakan akan terjadi gangguan proses reproduksi yang kurang sempurna, ikan mudah stress, dan juga dapat menyebabkan ikan mudah terserang penyakit (Afrianto dan Liviawaty, 2005). Menurut Murtidjo (2001), protein mutlak diperlukan dalam pakan ikan Lele Dumbo. Sedangkan perlakuan pemberian pada level pakan komersil $70 \%+30 \% \%$ pakan pelet organik $\left(\mathrm{P}_{3}\right)$ menunjukkan angka protein yang terendah dari semua perlakuan yaitu 29,56\%, hal ini bertolak belakang dengan Halver dan Hardy (2002), menyatakan bahwa kebutuhan kadar protein lebih dari 30\% untuk tumbuh maksimal ikan Lele Dumbo.

\section{Konsumsi pakan}

Pemberian pakan dalam penelitian ini dihitung berdasarkan bobot badan ikan Lele Dumbo/ekor dikali persentase pakan yang dibutuhkan lalu dikalikan dengan prakiraaan hidup (kebutuhan pakan 8\% dan prakiraan hidup 90\%). Adanya perbedaan yang sangat nyata pada level pemberian pakan komersil $90 \%+$ $10 \%$ pakan pelet organik $\left(\mathrm{P}_{1}\right)$, dengan perlakuan pemberian pakan komesildan penambahan 0,20 , dan $30 \%$ pakan pelet organik,

Pakan perlakuan pemberian pada level pakan komersil 100\%, tidak memperlihatkan pebedaan yang nyata dengan perlakuan pemberian pada level pakan $80 \%+20 \%$ pakan pelet organik $\left(\mathrm{P}_{2}\right)$ dan pada level pemberian pakan komersil $70 \%+30 \%$ pakan pelet organik $\left(\mathrm{P}_{3}\right)$ terhadap konsumsi pakan ikan Lele Dumbo, namun memperlihatkan perbedaan yang sangat nyata dengan perlakuan pemberian pada level pakan komersil $90 \%+10 \%$ pakan pelet organik $\left(\mathrm{P}_{1}\right)$, dengan demikian pakan asal limbah feses sapi mempunyai tingkat palatabilitas yang tinggi dengan penambahan pakan pelet organik $10-20 \%$ terhadap konsumsi ikan Lele Dumbo.

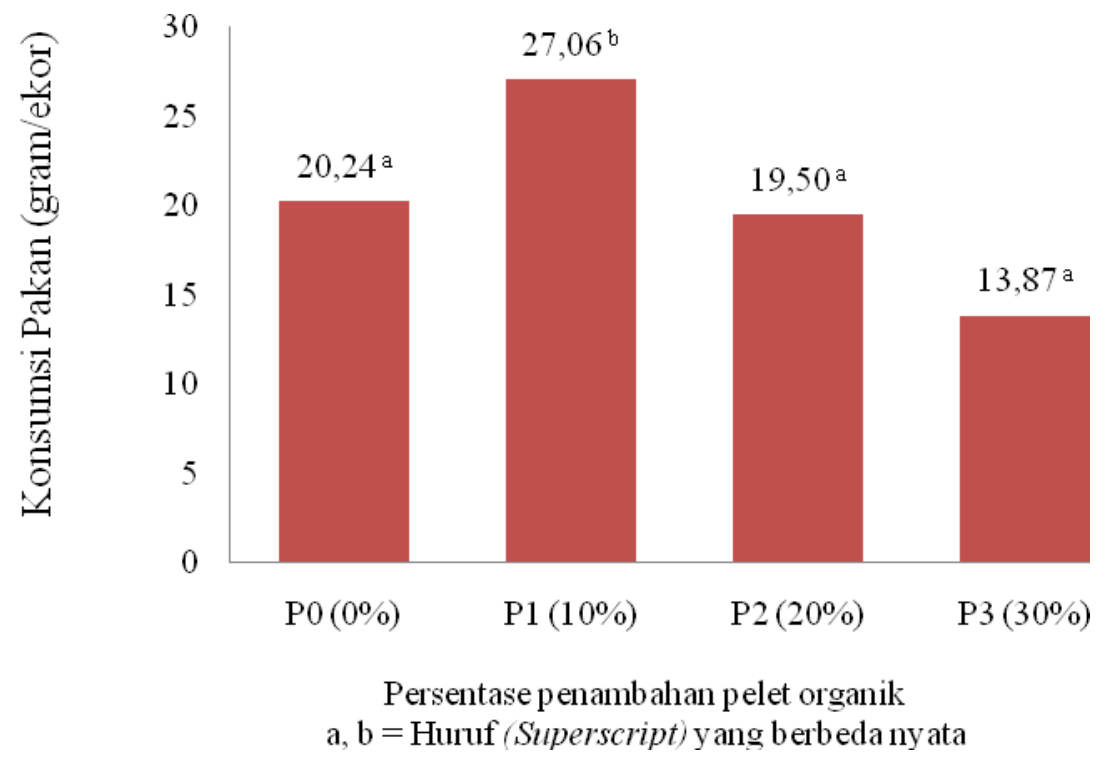

Gambar 3. Rataan konsumsi pakan ikan Lele Dumbo

Setiap perlakuan selama 12 minggu (gram/ekor) 
Berdasarkan hasil hitungan nilai gizi pakan perlakuan pada level pemberian pakan komersil $70 \%+30 \%$ pakan pelet organik $\left(\mathrm{P}_{3}\right)$ mengandung komposisi serat kasar 6,86\% hal ini bertolak belakang dengan Mokoginta (1986), serat kasar yang dibutuhkan ikan Lele Dumbo lebih kecil 6\%, dengan tingginya serat kasar di dalam pakan maka semakin lama pakan akan dicerna oleh ikan. Menurut Brett (1971), jumlah pakan yang mampu dikonsumsi ikan setiap harinya merupakan salah satu faktor yang mempengaruhi potensi ikan untuk tumbuh secara maksimal dan laju konsumsi pakan harian berhubungan erat dengan kapasitas dan pengosongan perut.

Probiotik terbukti efektif dapat meningkatkan konsumsi pakan dan pertambahan bobot badan. Konsumsi pakan ikan Lele Dumbo yang dipelihara selama penelitian menghasilkan laju konsumsi yang tertinggi pada perlakuan pada level pakan komersil $90 \%+10 \%$ pakan pelet organik $\left(\mathrm{P}_{1}\right)$ sebesar 27,06 (gram/ekor) lebih direspon oleh ikan Lele Dumbo dibandingkan perlakuan lainnya, selanjutnya diikuti oleh perlakuan pada level pemeberian pakan komersil dengan penambahan pakan pelet organik 20 dan 30\%, sedangkan yang terkecil perlakuan pada level pakan komersil $70 \%+30 \%$ pakan pelet organik $\left(\mathrm{P}_{3}\right)$ mencapai 13,87 (gram/ekor) (Theodorou et al.,1990).

\section{Efisiensi Pakan}

Semakin tinggi nilai efisiensi pakan menunjukkan semakin tinggi nilai respon ikan terhadap pakan yang diberikan. Nilai efisiensi pakan ikan Lele Dumbo dalam penelitian ini relatif berbeda, nilai efisiensi pakan dihitung dengan perbandingan antara pertambahan berat badan dengan pakan yang dikonsumsi dan dinyatakan dalam gram. Rataan efisiensi pakan perlakuan selama penelitian diperlihatkan pada Gambar 4.

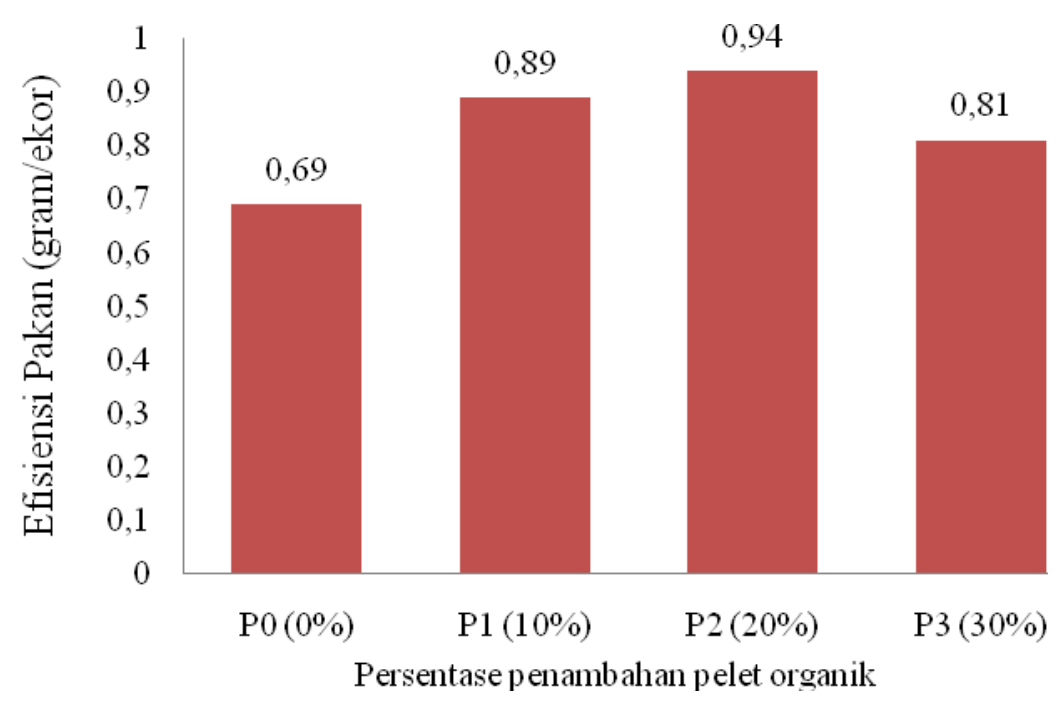

Gambar 4. Rataan efisiensi pakan ikan Lele Dumbo Setiap perlakuan selama 12 minggu (gram/ekor) 
Berdasarkan hasil penelitian memperoleh data tidak berpengaruh nyata terhadap efisiensi pakan ikan Lele Dumbo, namun perlakuan pada level pemberian pakan komersil $80 \%+20 \%$ pakan pelet organik $\left(\mathrm{P}_{2}\right)$ dan perlakuan pada level pemberian pakan komersil $90 \%+10 \%$ pakan pelet organik $\left(\mathrm{P}_{1}\right)$ menunjukkan angka yang tertinggi dibandingkan pakan perlakuan pada level pemberian pakan komersil $70 \%+30 \%$ pakan pelet organik $\left(\mathrm{P}_{3}\right)$ dan perlakuan pemberian pakan komersil 100\% $\left(\mathrm{P}_{0}\right)$ pakan kontrol.

Kecernaan pakan merupakan salah satu indikator yang dapat digunakan untuk menilai tingkat efisiensi pakan yang diberikan kepada ikan. Pakan yang diberikan kepada ikan tidak hanya dinilai dari nutrisi yang ada didalam pakan, namun seberapa besar nilai nutrisi didalam pakan mampu diserap dan dimanfaatkan oleh ikan, nilai kecernaan pakan menggambarkan bagian nutrisi atau energi pakan yang dicerna oleh ikan (NRC, 1993).

Tingkat kecernaan pakan dipengaruhi oleh banyak faktor, seperti kualitas dan kuantitas pakan, bahan pakan, kandungan gizi pakan, serta aktivitas enzimenzim pencernaan ikan, ukuran dan umur ikan, serta sifat fisik dan kimiawi perairan. NRC (1993), mengutip banyak peneliti yang menyatakan untuk beberapa jenis ikan, kecernaan pakan dipengaruhi oleh pakan. Henken et al. (1985), menyatakan bahwa peningkatan tingkat pemberian pakan menyebabkan penurunan kecernaan pakan pada ikan Lele Dumbo.

\section{Konversi pakan}

Konversi pakan merupakan perbandingan antara jumlah pakan yang diberikan dengan jumlah bobot ikan yang dihasilkan, semakin kecil nilai konversi pakan berarti tingkat efisiensi pemanfaatan pakan lebih baik, sebaliknya apabila konversi pakan besar, maka tingkat efisiensi pemanfaatan pakan kurang baik. Konversi pakan menggambarkan tingkat efisiensi pemanfaatan pakan yang dicapai (Hariati, 1989).

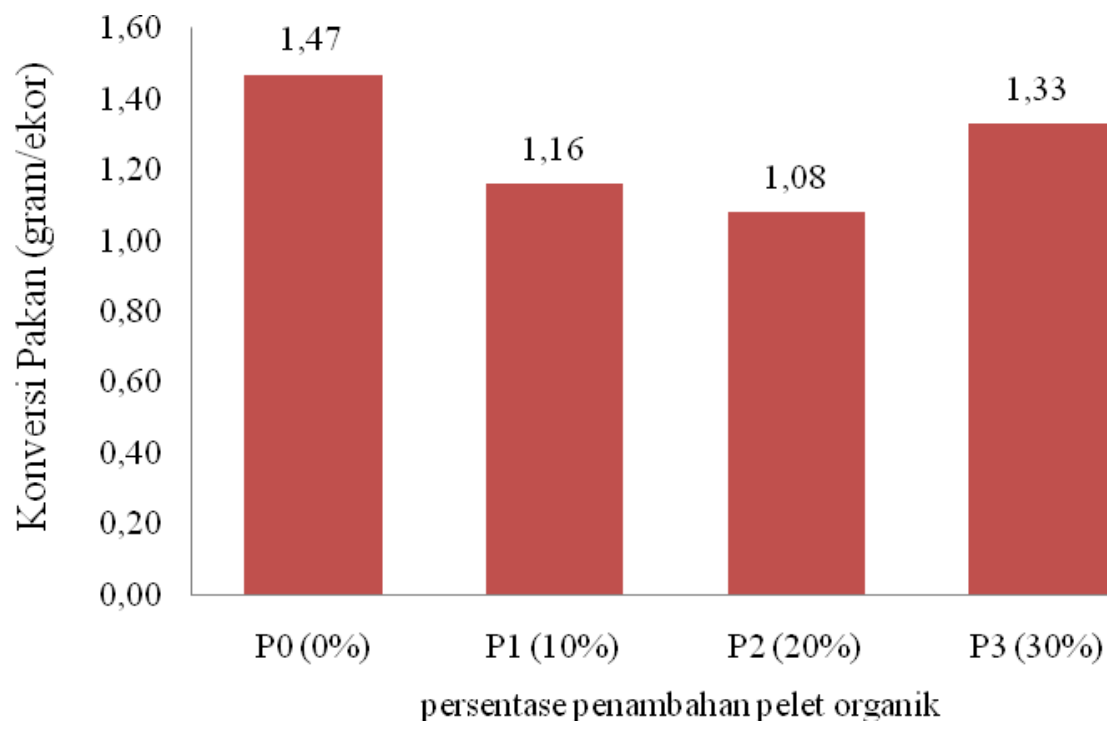

Gambar 5. Rataan konversi pakan ikan Lele Dumbo

Setiap perlakuan selama 12 minggu (gram/ekor) 
Berdasarkan hasil penelitian memperoleh data tidak berpengaruh nyata terhadap konversi pakan ikan Lele Dumbo. Menurut Sutardi (1990), konversi pakan sangat dipengaruhi oleh kualitas pakan, faktor lingkungan serta dengan kondisi ternak, jenis kelamin, kualitas pakan, dan daya cerna ternak itu sendiri. Effendi (2004), menyatakan konversi pakan tergantung pada spesies ikan (kebiasaan makan, dan ukuran) yang dikulturkan, dan kualitas air. Namun pakan perlakuan pemberian pada level pakan komersil $80 \%+20 \%$ pakan pelet organik $\left(\mathrm{P}_{2}\right)$ menunjukkan angka yang tertinggi dibandingkan pakan perlakuan pemberian pada level pakan komersil ditambahakan 10, 30, dan $0 \%$ pakan pelet organik.

\section{Kelangsungan Hidup Ikan Lele Dumbo (Survival rate)}

Kelangsungan hidup atau Survival rate (SR) merupakan persentase ikan uji yang hidup pada akhir penelitian dari jumlah ikan uji yang ditebar pada saat pemeliharaan dalam suatu wadah, kelangsungan hidup ikan Lele Dumbo dalam penelitian ini mencapai 100\%. Menurut Effendi (1979), tingkat kelangsungan hidup merupakan nilai persentase jumlah ikan yang hidup selama periode pemeliharaan. Kordi (2009), menyatakan bahwa rendahnya kelangsungan hidup suatu biota budidaya dipengaruhi beberapa faktor salah satunya nutrisi pakan yang tidak sesuai. Sistem ketahanan tubuh ikan semakin kuat apabila semua kebutuhan nutrisi tercukupi, kekebalan tubuh yang baik dapat menghasilkan kelangsungan hidup yang baik.

Tabel 1. Rataan Kelangsungan hidup ikan Lele Dumbo selama penelitian

\begin{tabular}{cccccc}
\hline \multirow{2}{*}{ Ulangan } & \multicolumn{4}{c}{ Kelangsungan Hidup (ekor) } & \multirow{2}{*}{ Total } \\
\cline { 2 - 4 } & $\mathrm{P}_{0}$ & $\mathrm{P}_{1}$ & $\mathrm{P}_{2}$ & $\mathrm{P}_{3}$ & \\
\hline 1 & 50 & 50 & 50 & 50 & 200 \\
2 & 50 & 50 & 50 & 50 & 200 \\
3 & 50 & 50 & 50 & 50 & 200 \\
4 & 50 & 50 & 50 & 50 & 200 \\
\hline Total & 200 & 200 & 200 & 200 & 800 \\
\hline Keterangan: & $\mathrm{P}_{0}=$ Pakan Komersil 781 (100\%) & \\
& $\mathrm{P}_{1}=$ Pakan Komersil 781 (90\%) + Pakan Pelet Organik (10\%) \\
& $\mathrm{P}_{2}=$ Pakan Komersil 781 (80\%) + Pakan Pelet Organik (20\%) \\
& $\mathrm{P}_{3}=$ Pakan Komersil 781 (70\%) + Pakan Pelet Organik (30\%)
\end{tabular}

Selama penelitian pengaruh pemberian pakan asal limbah feses sapi tidak adanya angka kematian atau Survival rate namun sebaliknya menunjukkan pakan limbah feses ini dapat menjaga kelangsungan hidup ikan. Menurut Yuniarti (2006), beberapa faktor yang berpengaruh terhadap tingkat kelangsungan hidup antara lain penyakit dan kualitas air ikan Lele Dumbo, penyakit yang menyerang biasanya berkaitan dengan kualitas air, kualitas air yang baik akan mengurangi resiko ikan terserang penyakit dan meningkatkan tingkat kelangsungan hidup (Survival rate). Menurut Murjani (2011), kelangsungan hidup ikan sangat bergantung pada daya adaptasi ikan terhadap makanan dan lingkungan, status kesehatan ikan, padat tebar, dan kualitas air yang cukup mendukung pertumbuhan.

Kualitas air secara langsung maupun tidak langsung kualitas air berpengaruh terhadap pertumbuhan ikan yang dikulturkan, parameter kualitas air 
yang diamati pada media pemeliharaan selama penelitian mencapai $25-30^{\circ} \mathrm{C}$, kisaran ini masih berada pada kisaran yang wajar. Menurut Rahardi (1996), suhu air kolam berkisar antara $25-30^{\circ} \mathrm{C}$ dengan perbedaan suhu antara siang dan malam hari tidak lebih dari $5^{\circ} \mathrm{C}$. Kelembaban kolam 80-95\%, cahaya yang masuk ke kolam 500-900\%, masuknya sinar matahari yang masuk kedalam kolam dipengaruhi oleh keadaan cuaca sekitar penelitian, derajat keasaman air $(\mathrm{pH})$ selama penelitian berkisar antara 6,5-7. Menurut Susanto (1999), umumnya pH yang sangat cocok untuk semua jenis ikan berkisar antara 6,7-8,6. Kisaran $\mathrm{pH}$ selama masa pemeliharaan masih termasuk dalam kisaran yang baik bagi kelangsungan hidup ikan Lele Dumbo. Menurut Djariah (1995), ikan dapat tumbuh dengan baik pada kisaran $\mathrm{pH}$ antara 6,5-8,5. Hal ini juga serupa seperti yang dinyatakan Arie (2007), kisaran $\mathrm{pH}$ yang di perlukan oleh ikan Lele Dumbo yaitu 6-9.

Kolam ikan yang sering digunakan pembudidaya ikan Lele Dumbo terbagi dua jenis yaitu kolam terpal dan kolam tanah. Kedua jenis kolam budidaya ikan Lele Dumbo tersebut memiliki kelebihan dan kekurangan. Pemeliharaan menggunakan kolam tanah (tambak) sangat bagus untuk menumbuhkan mikroorganisme air yang menyuplai dari unsur hara pada tanah, namun dengan pemakaian jangka panjang dapat menurunkan kualitas air. Menurut Kordi dan Tancung (2007), penurunan ini disebabkan pengoperasian lahan tambak dan kolam yang dilakukan terus-menerus tanpa istirahat, memacu produksi dengan padat penebaran dan pemberian pakan yang berlebihan serta penggunaan bahan kimia yang dapat merusak lingkungan.

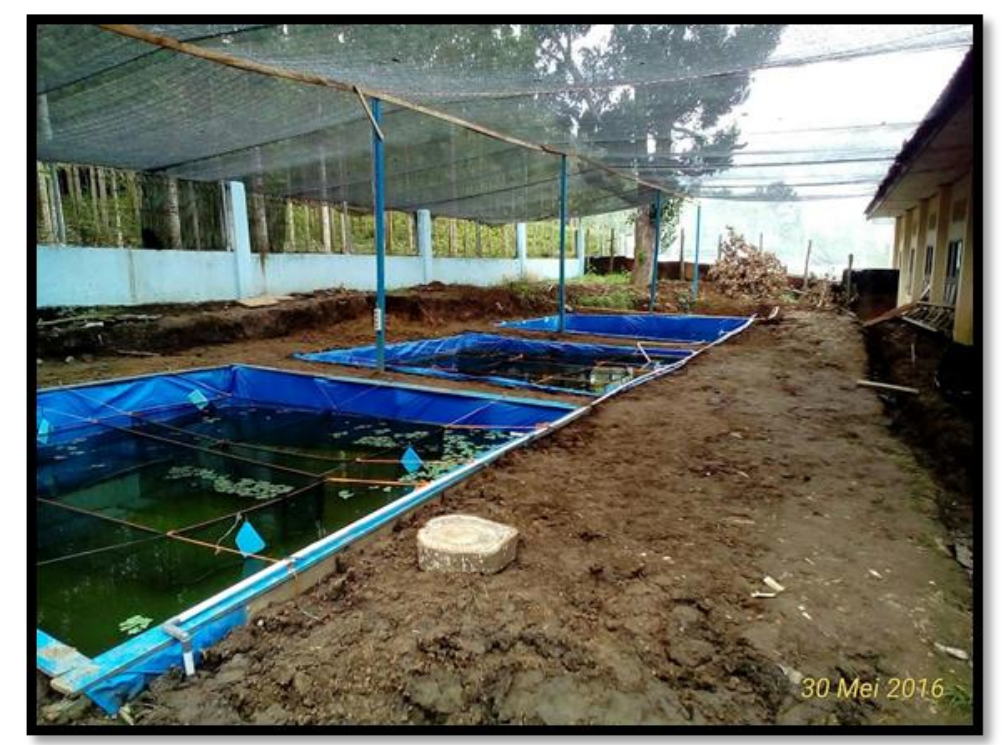

Gambar 10. Kolam terpal penelitian di Station Riset II (dua) Ie Seum UPT. University Farm, Universitas Syiah Kuala, Aceh Besar Sumber : Dokumen penelitian (2016).

Kolam yang digunakan pada penelitian ini adalah kolam terpal. Kelebihan kolam terpal dapat diaplikasikan di daerah yang kurang sumber air, suhu kolam lebih stabil, pemanenan menjadi lebih mudah, ikan tidak berbau tanah, jarang ditemui hama dan penyakit, kelangsungan hidup ikan lebih tinggi. Namun kolam 
terpal memiliki beberapa kelemahan, salah satunya mudah lapuk karna hujan, tidak tahan lama, dan air kolam terpal lebih cepat bau, berdasarkan dari kekurangan kolam terpal tersebut masih bisa ditolerin pembudidaya.

Peningkatkan kualitas air kolam bertujuan menghidupkan mikroorganisme dalam kolam sebagai pakan alami ikan dapat ditingkatkan dengan memanfaatkan probiotik. Probiotik Raja Lele yang digunakan mempunyai kandungan Lactobacillus, Acetobacter dan Yeast. Menurut Arief et al.(2008), bakteri yang paling efektif dalam meningkatkan kualitas air adalah bakteri dari jenis Bacillus dan Acetobacter.

\section{KESIMPULAN DAN SARAN}

\section{Kesimpulan}

Berdasarkan hasil penelitian yang telah dilakukandi Station Riset II (dua) Ie Suum, UPT. University Farm, Aceh Besar, terkait dengan pemanfaatan pakan organik asal feses sapi dapat disimpulkan bahwa subtitusi pakan pelet organik kedalam pakan komersil dapat digunakan sampai 20\%. Pakan organik asal limbah feses sapi berpengaruh terhadap berat badan, pertambahan berat badan dan konsumsi pakan ikan Lele Dumbo. Namun demikian, perlakuan tidak berpengaruh terhadap efisiensi dan konversi pakan ikanLele Dumbo.

\section{Saran}

Perlu dilakukan penelitian lanjutan mengenai pembuatan pakan pelet organik ini dengan subtitusi lebih dari $20 \%$ yang bahannya berasal dari berbagai hasil limbah peternakan dengan kombinasi bahan limbah lainnya.

\section{DAFTAR PUSTAKA}

Afrianto, E dan Liviawaty, E. 2005. Pakan Ikan. Kanasius. Yogyakarta : Penerbit Kanisius.

Arie, U. 2007. Pembenihan dan Pembesaran Nila Gift. Cetakan Keenam. Penebar Swadaya. Jakarta. Hal. 7-79.

Arief, M, Mufidah, dan Kusriningrum. 2008. Pengaruh penam-bahan probiotik pada pakan buatan terhadap pertumbuhan dan rasio konversi pakan ikan nila gift (Oreochromis niloticus). Berkala Ilmiah Perikanan 3 (2): 53-58.

Brett, J. R. 1971. Satiation time, appetite and maximum food intake of socheye salmon (Onchorhyncus nerka). J. Fish. Bd. Canada, 28: 409-415.

Djariah, A. S. 1995. Pakan Ikan Alami. Kanisius. Yogyakarta.

Effendi, M. I. 1979. Metode Biologi Perikanan. Yayasan Dewi Sri. Bogor.

.2004. Pengantar Akuakultur. Penebar Swadaya. Jakarta.

Halver, J. E. And Hardy, R. W. 1988. Fish Nutrition. Academic Press, Inc. San Diego-California.798 pp.

Hariati, A. M. 1989. Makanan Ikan.LUW/UNIBRAW/Fish Fisheries Project Malang. 99 hal. 
Henken, A. M, Kleingeld, D. W., and Tijssen, P. A. T. 1985. The effect of feeding level on apperent digestibility of dietary dry matter. Crude protein and gross energy in the African catfish Clarias gariepinus (Burchel, 1822). Aquaculture, 51: 1-11.

Kordi, K. M. G. H. 2009. Budidaya Perairan. Citra Ditya Bakti. Bandung.

Kordi, K. M. G. H dan Tancung, A. B. 2007. Pengelolaan Kualitas Air dalam Budidaya Perairan. PT. Rhineka Cipta. Jakarta.

Madinawati, Serdiati, N, dan Yoel. 2011. Pemberian Pakan Yang Berbeda Terhadap Pertumbuhan Dan Kelangsungan Hidup Benih Ikan Lele Dumbo (Clarias gariepinus). Media Litbang Sulteng. IV (2) : 83 - 87, (Diakses Agustus 2014)

Murjani, A. 2011. Budidaya beberapa varietas ikan sepat rawa (Trichogaster trichopterus Pall) dengan pemberian pakan komersial. Jurnal Fish Scientiae.1(2): 214-233.

Murtidjo, B. A. 2001. Pedoman Meramu Pakan Ikan. Yogyakarta : Penerbit Kanisius.

NRC. 1993. Nutien Requirement of Fish. National Academy Press. Washington D.C. 102 pp.

Parakkasi, A. 1999. Ilmu Nutrisi dan Makanan Ternak Ruminan. Cetakan Pertama. Penerbit UIP, Jakarta.

Pramono, T. 2007. Optimasi Pakan dengan Level Protein dan Energi Protein untuk Pertumbuhan Calon Induk Ikan Senggaringan (Mystus nigriceps). Jurnal Protein. Vol. 15 No.2.

Rahardi. 1996. Agribinis Perikanan. Penebar Swadaya. Jakarta.

Soedarno, P dan Sedioetama, A. D. 1974. Ilmu Gizi. Jakarta : Dian Rakyat.

Subandiyono. 2009. Bahan Ajar Nutrisi Ikan (Karbohidrat, Mikro-Nutrien ,NonNutrien dan Anti-Nutrien). Program Studi. Budidaya perairan, jurusan Perikanan. Fakultas Perikanan dan Ilmu Kelautan. Universitas Diponegoro.

Susanto. 1999. Komunikasi dalam Teori dan Praktek. Jakarta: Bina Cipta.

Sutardi, T. 1980. Landasan Ilmu Nutrisi . Jilid I. Departemen Ilmu Makanan Ternak Fakultas Peternakan Institut Pertanian, Bogor. Teknologi Bandung. Bandung.

Theodorou, M .K., D.E . Boever, M .J . Haines and Brooks, A . 1990 . The effect of fungal probiotic on intake and performance of early weaned calves . Anim. Prod . $53: 577$.

Yuniarti. 2006. Pengaruh Kepadatan Benih Ikan Lele Dumbo (Clarias sp) Terhadap Produksi pada Sistem Budi daya dengan Pnegndalian Nitrogen melalui Penambahan Tepung Terigu. Skripsi. Bogor. 